\title{
Sequential Explanatory Analysis for Increasing Teacher Innovation through Strengthening Organization Climate, Situational Leadership, and Commitments to Organizations
}

\author{
Andi Chairunnas*, Soewarto Hardhienata, Bibin Rubini \\ PostgraduateProgram, Pakuan University, Bogor, Indonesia \\ *Corresponding Author: Andi Chairunnas, Postgraduate Program, Pakuan University, Bogor, \\ Indonesia
}

\begin{abstract}
This research aims to find efforts to find out the ways to overcome the low level of teachers' innovation by examining organizational climate, situational leadership and commitment to the organization. The sample chosen was 186 teachers, with the criteria of private teachers in Makassar, South Sulawesi Province, Indonesia. This study uses a Mixed Sequential Explanatory Method, which is the first research using quantitative methods and then to deepen the research conducted with qualitative methods. This is intended to make the results of study more in-depth and comprehensive. Based on these results, an analysis is then performed using the SITOREM method to set recommendations and determine the priority order for handling the indicators that must be corrected. The quantitative research results found that all variables have a relationship significantly positive with teacher innovation. In line with the results of quantitative analysis, the results of qualitative data analysis also show that teacher innovation can be improved through improving organizational climate, situational leadership and commitment to the organization. SITOREM analysis results show that the components of teacher innovation, organizational climate, situational leadership and commitment to teacher organizations need improvement is 1) obligation to moral responsibility, 2) emotional connection, 3) supportive management, 4) appreciation, 5) recognition of position and achievement, 6) freedom of expression, 7) delegation style, 8) participatory style, 9) work plan, 10) service innovation, 11) multimedia, 12) continuous service. In addition the components that need to be maintained include: 1) awareness of perceived economic value, 2) obligations to formal duties, 3) confidence in values, 4) loyalty to survive as a member of the organization, 5) policy, 6) contribution, 7 ) supportive style, 8) selling style, 9) telling style, 10) work strategy and 11) work methods. The results imply corrective action necessary for the respective school.
\end{abstract}

Keywords: SITOREM Analysis, Teacher Innovation, Organizational Climate, Situational Leadership and Commitment to the Organization

\section{INTRODUCTION}

Article 3 of Law No. 20/2003 states that "National education functions to develop capabilities and shape the character and civilization of a dignified nation in order to educate the life of the country, aiming at improving the potential to become human beings who believe and fear God Almighty, noble, healthy, knowledgeable, creative, independent, and become citizens who are democratic and responsible ". Vocational High School is one type of secondary education institution in Indonesia. The implementation of education is designed to prepare students for employment.

Vocational Secondary Education is education at the secondary education level that prioritizes developing the ability of students to carry out certain types of work. Vocational High School prioritizes preparing students to enter the workforce as well as developing professional attitudes. Following its form, Vocational High School organizes educational programs tailored to the types of. Observing the formulation of educational goals according to Law No. 20/2003, it can be said that the development of education in Indonesia has actually tried to lead to the development of whole people. This is done to answer the challenges of the development of civilization so that the development of right education leads to efforts to prepare humans to become someone who can fulfil their life functions not only for themselves but also for society, nation and even the international world. For this reason, humans are also prepared to be able to assume responsibility for all their actions. 
Initial survey results in preliminary research on teacher innovation show that private Vocational High School teachers in the Makassar city area are still not as expected in terms of innovation, both in product innovation, process innovation and service innovation. There are 57\% of teachers who have problems in terms of innovation in the aspects of the plan that is not yet re-modelling the learning implementation plan. There are 50\% of teachers who have issues in terms of innovation in the elements of the plan that is not yet making a lesson plan that is relevant to new developments globally both fundamental knowledge and applied science.

The indications mentioned above are considered important and become a benchmark that the innovation of teachers in Vocational High Schools is still low in Makassar. The teacher does not have new ideas in class to develop learning patterns in the classroom as well as the creation of new learning media and teaching aids, classroom management and management that is fun and not monotonous and makes students saturated in class. The teacher does not provide examples and experiences that can be synergized with other teachers in creating new tools or simulations and roles that can stimulate student creativity. Increasing the innovation of teachers to be able to innovate, the school demands a large contribution from teachers to be more creative and to do more activities than is available. The demand from the school for teachers to be more creative and make innovative breakthroughs will not be able to be overcome without the support of strengthening the organizational climate and commitment to the organization within the teacher concerned. Increasing the competence of teachers cannot only rely on the teacher's self-effort, but also there must be opportunities given from the school. Based on the identification and restriction of the problem, it can be proposed that the primary problem formulation is whether teacher innovation can be improved through strengthening the organizational climate, situational leadership, and commitment to the organization. While the formulation of the problem includes:

- Is there a relationship between organizational climate and teacher innovation?

- Is there a relationship between situational leadership and teacher innovation?

- Is there a relationship between commitment to the organization and teacher innovation?

- Is there a relationship between organizational climate, situational leadership and commitment to the organization together with teacher innovation?

\section{LITERATURE REVIEW}

\subsection{Innovation}

According to Dawson (2014), innovation is the process of creating new ideas and putting them into practice. This innovation is a means of creative ideas that can be applied by someone into daily practice, i.e. methods that contribute to improving customer service or organizational productivity. The dimensions of this innovation include a. Idea creation, which is to make an idea through spontaneous creativity, ingenuity, and information processing, $b$. Initial experiments, namely to build the potential value of ideas and applications, c. Eligibility of determination, namely to identify the expected costs and benefits, $d$. The final application, which is to produce and market new products or services, or to implement new approaches to operations.

Adenjii (2011), innovation is the transformation of knowledge into new products, processes and services, the act of using something new. Further Abbas et al (2018) confirm that innovation is the successful exploitation of a new idea or in other words is the mobilization of knowledge, technological skills and experience to create new products, processes and services.

\subsection{Organizational Climate}

According to Dele (2015), organizational climate represents the perceptions of organizational members regarding management policies and practices. The factors are a. Superior-subordinate relationship, b. Communication between members of the organization, c. Members' perceptions of organizational policies, d. Members' perception of management practices (fairness). This implies that the higher the level of superior-subordinate relations, the level of communication between members of the organization, the level of members 'perceptions of organizational policies, the level of members' perceptions of management practices (fairness), the higher the level of organizational climate 


\subsection{Situational Leadership}

According to Gibson (2012), situational leadership is the use of leadership styles that are considered appropriate according to the level of maturity or readiness of followers. Factors that support it are a. Telling, the leader gives direction, b. Selling, i.e. the leader gives orderly instructions, c. Participating, namely, leaders and subordinates share in solving problems, d. Delegating, the leader who gives a little direction or personal approach. While Bertocci (2009) formulates situational leadership as leadership that pays attention to the character of the leader himself, the nature of a job, the nature of the organization and the nature of who becomes his followers. The leader who carries out his leadership effectively is determined by the factors of identification of the character of oneself, work, organization, and followers.

\subsection{Commitment to the Organization}

According to George (2015), commitment to the organization is the emotional bond of employees to identify themselves and involve themselves in specific organizations. Organizational Commitment is built from five dimensions, namely: a - Justice and support, b. Shared values, c. Trust, d. Organizational understanding, and e. Employee involvement. According to King (2016), organizational commitment as a relative strength of individual identification of an organization and its involvement in a particular organization. That is a. definite trust and acceptance of the organization's values and goals. b. The desire to try hard for the sake of the organization. c. A strong desire to remain a member of the organization.

Based on the above frame of thinking, a research hypothesis can be derived: teacher innovation can be improved through strengthening the organizational climate, situational leadership, and commitment to organizations with the following assumptions:

- There is a positive relationship between Organizational Climate and Teacher Innovation.

- There is a positive relationship between Situational Leadership and Teacher Innovation.

- There is a positive relationship between Organizational Commitment and Teacher Innovation

- There is a positive relationship between Organizational Climate, Situational Leadership and Commitment to the Organization together with Teacher Innovation.

\section{METHODS}

This study uses a combination of design research methods sequential explanatory. The research method of combination design sequential explanatory is a combination research method that combines quantitative and qualitative research methods sequentially, where in the first stage the research is carried out using quantitative methods and in the second stage is carried out with qualitative methods. Quantitative methods play a role to obtain measurable quantitative data, in this research are associative, and qualitative methods play a role in proving, deepening, expanding, giving meaning to quantitative data that was obtained at an early stage. The population in this study were teachers and taught in Makassar Private Vocational Schools with the status of Permanent Teachers, totaling 346 people from 17 schools. This population was chosen given the limitations that exist both in terms of knowledge, time and funds, so this study was limited only to the author's value is affordable. Determination of the sample in this study using the Slovin formula to obtain a total sample of 186. Sampling using simple random or Proportional Random Sampling. Data collection techniques in this study used in-depth interviews with Focus Group Discussion, observation and documentation. The data analysis technique used in this study is descriptive and inferential data analysis techniques (Hardhienata, 2017).

\section{RESULTS AND DISCUSSION}

\subsection{The Relationship between the Organizational Climate Innovation of Private Vocational in Makassar City}

The relationship between Organizational Climate Model with Innovation Master can be expressed in a simple linear regression equation $\mathrm{y}=78.758+0.297 \mathrm{X}_{1}$, which means that any increase in the unit value of Organizational Climate will be followed by an increase Teacher Innovation value of 0.297 units with a constant of 78.758 . The regression equation $\mathrm{y}=78.758+0.297 \mathrm{X}_{1}$ can be used to predict the score Innovation Master if the score Organizational Climate known. 
The correlation coefficient $\left(\mathrm{r}_{\mathrm{y} 1}\right)$ of 0.394 shows a positive relationship between Organizational Climate and Teacher Innovation. The contribution of Organizational Climate is shown by the coefficient of determination $\left(\mathrm{r}_{\mathrm{y} 1}{ }^{2}\right)$ of 0.1557 , which means that Organizational Climate contributes $15.57 \%$ to Teacher Innovation, while the remaining $84.43 \%$ is determined by other variables. Innovation is the process of creating new ideas and putting them into practice. This innovation is a means of creative ideas that can be applied by someone into daily practice, i.e. practices that contribute to improving customer service or organizational productivity. Organizational Climate is a representation of the perceptions of organizational members about management policies and practices. Organizational climate is also a collection and environmental pattern that determines motivation.

A conducive organizational climate can make organizations develop more solid, stronger and organizational goals can be accommodated well. The favourable Organizational Climate, which is part of the Organizational Climate, is one of the factors that influence Teacher Innovation. However, in reality, there are still many teachers who feel that the work environment is not conducive to school, so teachers will not be able to improve, and if teachers do not increase, students will achieve unsatisfactory academic performance.

The results of research conducted by Warren (2014), concluded that there is a related relationship between Climate Organizational and significant innovations on organizational results. School organizations can be defined as any (non-physical) situations arising from the relationship between management schools and teachers, teachers and students, or managing relationships with other school employees in the teaching and learning process. This non-physical situation can be understood as a dimension used by some experts with terms, such as cooperation, satisfaction, speed, formality, difficulty, and democracy from school. This implies that the more established cooperation, satisfaction, speed, formality, difficulties, democracy, the higher the relationship between school management and teachers in the school organization climate.

Qualitative data aims to strengthen and deepen quantitative research results. Based on the results of the interviews, the teachers generally felt grateful for the rewards and awards they received. The teachers also have the opportunity to attend the training needed and become a school representative to participate in various activities outside the school by available funds.

\subsection{Relationship between Situational Leadership in Innovation of Private Vocational School}

Model situational leadership relationship between the variables with the innovation variables can be expressed in a simple linear regression equation $y=89.72+0.196 \mathrm{x}_{2}$, which means that any increase in the unit value of situational leadership will be followed by an increase in the value of teacher innovation of 0.196 units with a constant of 89.72 . The regression equation $y=89.72+0.196 x_{2}$ could be used to predict the score innovation master if the score situational leadership knew.

The correlation coefficient $\left(\mathrm{r}_{\mathrm{y} 2}\right)$ of 0.256 shows a positive relationship between Situational Leadership and Teacher Innovation. The contribution of Situational Leadership is shown by the coefficient of determination $\left(\mathrm{r}_{\mathrm{y} 2}{ }^{2}\right)$ of 0.0659 which means that Situational Leadership contributes $6.59 \%$ to Teacher Innovation, while the remaining $93.41 \%$ is determined by other variables.

The significant positive relationship between situational leadership and teacher innovation has also been proven by the results of previous studies such as those conducted by Warren (2015), who showed that there was a very significant positive relationship with the regression equation $\hat{y}=72.11+$ $0.420 \times 2$ with $\mathrm{r}=21.01 \%$.

Qualitative data that aims to strengthen and deepen the results of quantitative research indicates that the majority of teachers assess that the leadership of their principals is good. But if you look at the results of quantitative research shown by the correlation coefficient $\left(\mathrm{r}_{\mathrm{y} 2}\right)$ of 0.256 , it shows that the relationship between Situational Leadership and Teacher Innovation is still relatively weak. It is also seen in the contribution of Situational Leadership shown by the coefficient of determination $\left(\mathrm{r}_{\mathrm{y}_{2}}{ }^{2}\right)$ of $0.0659(6.59 \%)$ which means that Situational Leadership contributes only 6.59\% to Teacher Innovation, while the remaining $93,41 \%$ is determined by other variables.

Differences in the value of quantitative and qualitative research results can also indicate that when interviews with teachers are held, they do not dare to answer frankly about what is actually felt and personal opinions about the principal. Besides, because it is not easy to get actual data from 
interviews, also because teachers must maintain the honour of their leaders as well as the honour of the organization where they work.

\subsection{Relationship between Commitment to Organizations and Teacher Innovation of Private Vocational School}

The model of the relationship between commitment to organizations and teacher innovation can be expressed in a simple linear regression equation $\hat{y}=30.749+0.615 \mathrm{x}_{3}$ which means that every increase of one unit of value commitment to the organization will be followed by increasing the value of teacher innovation by 0.651 units with a constant of 30.749 . The regression equation $\hat{y}=30.749+0.61 x_{3}$ can be used to predict teacher innovation scores if the commitment to organizational score is known.

The correlation coefficient $\left(\mathrm{r}_{\mathrm{y} 3}\right)$ of 0.476 shows a positive relationship between commitment to the organization and teacher innovation. The contribution of commitment to the organization is shown by the coefficient of determination $\left(\mathrm{r}_{\mathrm{y} 3}{ }^{2}\right)$ of 0.2269 , which means that the commitment to the organization contributes $22.69 \%$ to teacher innovation, while the remaining $77.31 \%$ is determined by other variables.

Commitment to the organization is an emotional bond of employees to identify themselves and involve themselves in certain organizations. Commitment to the organization is built from five dimensions, including justice and support, shared values, trust, organizational understanding and employee involvement. Organizational commitment is defined as the multidimensional nature, involving employee loyalty, the desire to exert effort on behalf of the organization, the level of goals and values that are in line with the organization and the desire to maintain membership. The dimensions are: (1) normative commitment (2) continuance commitment (3) affective commitment (Seen, 2012).

The results of quantitative research data indicate the average total score of the commitment variable indicators for the organization is 4.0. Besides, based on empirical score data, the level of commitment to the organization is relatively good, and from the results of the frequency distribution data, there are around $34.9 \%$ of teachers who still have commitment to the organization below the average value. Qualitative data aims to strengthen and deepen quantitative research results.

\subsection{Relationship between Organizational Climate, Situational Leadership and Commitment to Organizations Together with Teacher Innovations of Private Vocational School}

Model of the relationship between Organizational Climate, Situational Leadership and Commitment to Organizations together with Teacher Innovation can be expressed in linear regression equations double $\hat{\mathrm{Y}}=17.184+0.317 \mathrm{X}_{1}+0.31 \mathrm{X}_{2}+0.496 \mathrm{X}_{3}$ which means that if the value of Organizational Climate, Situational Leadership value and the value of Commitment to the Organization increase by one unit, it will be followed by an increase in Teacher Innovation value of $0.317,0.031$ and 0.496 units with a constant 17,184 . The regression equation $\mathrm{y}=17.184+0,317 \mathrm{X}_{1}+0,031 \mathrm{X}_{2}+0,496 \mathrm{X}_{3}$ can be used to predict the score Innovation Master if the score of organizational climate, situational leadership and commitment to the organization is known.

The multiple correlation coefficient $\left(\mathrm{r}_{\mathrm{y} 123}\right)$ of 0.568 shows a positive relationship between Organizational Climate, Situational Leadership and Commitment to the Organization together with Teacher Innovation. The contribution of Organizational Climate, Situational Leadership and Commitment to the Organization together, is shown by the coefficient of determination $\left(\mathrm{r}_{\mathrm{y} 123}{ }^{2}\right)$ of 0.3232 which means that Organizational Climate, Situational Leadership and Commitment to the Organization together contribute $32.32 \%$ of Teacher Innovation, while the remaining of $67.68 \%$ is determined by other variables.

Based on the results of the study above, that the value of the multiple correlation coefficient $\left(\mathrm{r}_{\mathrm{y} 123}\right)$ of 0.568 shows that the relationship between Organizational Climate, situational leadership and Commitment to the Organization together with Teacher Innovation turns out to have the highest value. Thus, efforts to improve Teacher Innovation will be even better if carried out simultaneously with efforts to improve the Climate of the Organization of the foundation or the owner of the school, the Principal Situational Leadership and Commitment to Teacher Organizations.

Based on the calculation of the total average number of indicators, in general, it can be seen that all the total values of the average indicator have a value above the number 3 , but there is no total average 
value of the indicator that reaches the value of the number 5 . The measurement scale uses which starts from the highest score of 5 to the lowest score of 1 with a choice of answers always (score 5), often (score 4), sometimes (score 3), ever (score 2), never (score 1) and scale that starts from the highest score of 5 to the lowest score of 1 with a choice of answers strongly agree (score 5), agree (score 4), doubt (score 3), disagree (score 2) and strongly disagree (score 1 ) (Robbins,2016).

The measurement criteria on a score of 4 are already considered both on the rating scale (score four is often, which indicates the level of frequency of activity being asked), and on the scale (score four is agreed, which indicates the level of respondents' agreement to the statement). The indicators on each research variable that get the results of respondents' answers with a total score above a score of 4 should be maintained. While the indicators of research variables that get a total score below score 4, it should be followed up through an action plan which is a follow-up to the research results.

Follow-up results of the research (action plan) will be made in the planned program of activities that are expected to help provide alternative solutions related to several indicators of the research variables, so that they can provide a very significant contribution value to improve or enhance the problem of this research that is innovative (Uhlbien, 2012).

\subsection{SITOREM Analysis}

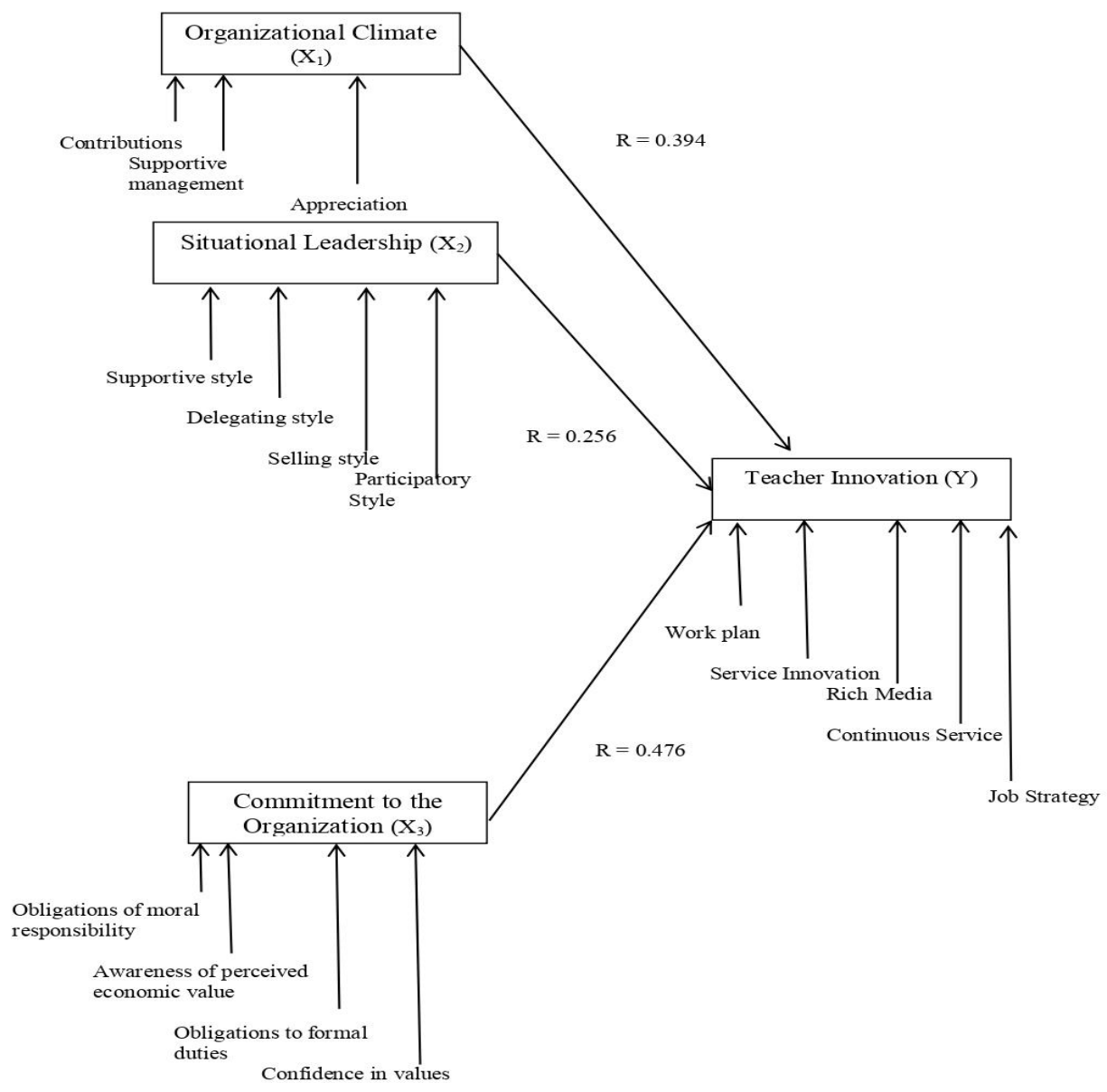

Figure1: Analysis of SITOREM (Scientific Identification Theory for Operational Research in Education)

\section{CONCLUSION}

Based on the discussion outlined, it can be concluded that teacher innovation can be improved through strengthening, organizational climate, situational leadership and commitment to the organization by improving indicators that are still weak and maintaining indicators that are already strong. The results of the statistical analysis show that:

- There is a positive relationship between organizational climate and teacher innovation with a moderate level of the correlation coefficient. The results of qualitative research indicate a tendency for the relationship between organizational climate and teacher innovation. SITOREM 
analysis shows that there are indicators that need to be improved, namely supportive management, appreciation, recognition of position and achievement and freedom of expression

- There is a positive relationship between situational leadership and teacher innovation with a low level of the correlation coefficient. Qualitative research results indicate a tendency between situational leadership with teacher innovation and SITOREM analysis shows that there are two indicators, namely delegating style and participatory style that must be improved.

- There is a positive relationship between commitment to the organization with teacher innovation with a moderate level of the correlation coefficient. Qualitative research results indicate a tendency between commitment to the organization with teacher innovation and SITOREM analysis shows that two indicators must be corrected, namely the obligation to moral responsibility and emotional connection

- There is a positive relationship between organizational climate, situational leadership, and commitment to the organization together with teacher innovation with a moderate level of the correlation coefficient.

\section{REFERENCES}

[1] Abbas, E. W., Hadi, S., \& Rajiani, I. (2018). The prospective innovator in public university by scrutinizing particular personality traits. Polish Journal of Management Studies, 18.

[2] Adeniji, A. A. (2011). Organizational climate as a predictor of employee job satisfaction: Evidence from Covenant University.Business intelligence journal, 4(1), 151-166.

[3] Bertocci, D. I. (2009). Leadership in organizations: There is a difference between leaders and managers University Press of America.

[4] Dawson, P., \&Andriopoulos, C. (2014). Managing change, creativity and innovation.Sage.

[5] Dele, A. O., Ezekiel, A. O., \&Alani, L. F. (2015). Strategic human resource management and organizational climate in the Nigerian Banking Industry. American Journal of Environmental Policy and Management, 1(3), 38-50.

[6] George, J. M., Jones, G. R., \& Sharbrough, W. C. (2015).Understanding and managing organizational behaviour. Upper Saddle River, NJ: Pearson Prentice Hall.

[7] Hardhienata, S., 2017, January.The development of scientific identification theory to conduct operation research in education management. In IOP Conference Series: Materials Science and Engineering (Vol. 166, No. 1, p. 012007). IOP Publishing.

[8] King, D. D., Newman, A., \& Luthans, F. (2016). Not if, but when we need resilience in the workplace. Journal of organizational behaviour, 37(5), 782-786

[9] Gibson, J. L., Ivancevich, J. M., Donnelly, J. H., \& Konopaske, R. (1991). Organizations: Behavior, structure, processes. Homewood, IL: Irwin.

[10] Warren, S. M. (2015). The leadership process: An analysis of follower influence on leader behaviour in hospital organizations (Doctoral dissertation, Pepperdine University).

[11] Seen, N. Y., Singh, S. K. G., \&Jayasingam, S. (2012). Organizational culture and innovation among Malaysian employees. The Journal of Human Resource and Adult Learning, 8(2), 147.

[12] Robbins, S. P., \& Judge, T. A. (2016). Organizational Behavior, Global 17th Edition.

[13] Uhl-Bien, M., SchermerhornJr, J. R., \& Osborn, R. N. (2014). Organizational Behavior, Experience Grow Contribute. 222 Rosewood Drive, Danvers, MA 01923: Clearance Center.

Citation: Andi Chairunnas, et.al. "Sequential Explanatory Analysis for Increasing Teacher Innovation through Strengthening Organization Climate, Situational Leadership, and Commitments to Organizations" International Journal of Managerial Studies and Research (IJMSR), vol 7, no. 12, 2019, pp. 40-46. doi: http:// dx.doi.org/10.20431/2349-0349.0712006.

Copyright: () 2019 Authors. This is an open-access article distributed under the terms of the Creative Commons Attribution License, which permits unrestricted use, distribution, and reproduction in any medium, provided the original author and source are credited. 